\title{
A CRITIQUE OF THE DEMISE OF HEADS OF STATE IMMUNITY IN THE AGE OF HUMAN RIGHTS*
}

\author{
SELMAN OZDAN**
}

\begin{abstract}
This paper presents an unspoken aspect of Head of State immunity, namely that such immunity is at odds with the expectation that international law should be applied to challenge resistance to and promote respect for human rights. It considers the question of whether Head of State immunity gives rise to de facto impunity in the case of violations of human rights recognised as peremptory norms (jus cogens) committed by such Heads of State. While this paper emphasises the critical role of Head of State immunity in the context of international relations, it argues that Heads of State should not exempt from punishment when violations of those human rights are at stake.
\end{abstract}

Keywords: Head of State, immunity, impunity, human rights, peremptory norms.

Summary: I. INTRODUCTION; II. DEVELOPMENTS OF HEAD OF STATE IMMUNITY IN INTERNATIONAL LEGAL SYSTEM; III. THE PROBLEM OF HEAD OF STATE IMMUNITY IN RELATION TO VIOLATIONS OF HUMAN RIGHTS RECOGNISED AS PEREMPTORY NORMS; IV. PROTECTION OF HUMAN RIGHTS VS. HEAD OF STATE IMPUNITY; V. CONCLUSION; VI. REFERENCES

\section{INTRODUCTION}

State officials have traditionally been immune from the jurisdiction of foreign States' courts when they would otherwise be required to account for the deeds they are accused of committing. However, this authoritative principle of international law becomes contentious in cases involving the violation of human rights recognised as peremptory norms, most strongly represented by the growth of international human rights law and the establishment of international tribunals and courts determined to end impunity for violations of those human rights, irrespective of the perpetrators' official position. ${ }^{1}$ Increasing concern for international human rights and greater international support for abolishing impunity for violators of those human rights have led the international community to question the boundaries of Head of State immunity.

\footnotetext{
* This article is based on Asst. Prof. Dr. Selman Ozdan's PhD dissertation which was conducted under the supervision of Prof. Jean Allain at Queen's University Belfast.

** Asst. Prof. Dr. in Public International Law at Erciyes University School of Law (Turkey). (selmanozdan@erciyes.edu.tr) He holds Ph.D. (2016) in Law from Queen’s University Belfast School of Law (United Kingdom) and LL.M. with Honors (2011) from Case Western Reserve University School of Law (Cleveland OH USA). He is a member of the Society of Legal Scholars (SLS) and Case Western Reserve University Law Alumni Association. ORCID ID: https://orcid.org/0000-0002-1002-0625

${ }^{1}$ Hazel Fox QC and Philippa Webb, The Law of State Immunity (3rd edn, Oxford University Press 2013) 537.
} 
There were great expectations that international law would evolve in favour of international human rights after the Second World War. These expectations undoubtedly continue. It would be a fantasy to imagine that international law always works in favour of human rights; however, there is a definite trend within the international community to seek to enhance and support international human rights. Head of State immunity appears to be a considerable impediment to realising the expectation that international law can be used to challenge resistance to respect for human rights and to ending impunity. In this sense, impunity 'must be distinguished from immunity; the two terms must not be used interchangeably'. ${ }^{2}$ Immunity is a general rule of international law 'whereby certain State officials are deemed to be endowed with immunity from criminal prosecution and civil suits initiated in foreign States. Impunity can be described as exemption from penalty or punishment. When the sovereign immunity principle is applied to the practice of sovereign impunity, individuals, who have administrated and participated in fundamental human rights violations, are often beyond the capacity of the law to provide a remedy'. ${ }^{3}$

This paper examines the tension between the principle of Head of State immunity and the protection of human rights recognised as peremptory norms under general international law. It considers the developments under international law in respect of the rules regarding such immunity. This paper subsequently discusses and analyses immunity and impunity for Heads of State when violations of human rights recognised as peremptory norms are perpetrated. To engage with this discussion, the paper concentrates on the judgement of the International Court of Justice in Arrest Warrant of 11 April 2000 (Democratic Republic of the Congo $v$ Belgium) so as to criticise the issue of immunity in question. Towards that end, the paper considers the question of whether Head of State immunity, in effect, means Head of State impunity in cases involving the violation of human rights recognised as peremptory norms. Here, the central aim of the paper is to argue that Head of State immunity leads to de facto impunity in the case of violations of those human rights. Finally, regarding the language of this paper, when the phrase fundamental human rights is used, it signifies or reads as human rights recognised as peremptory norms of general international law. ${ }^{4}$

\footnotetext{
${ }^{2}$ Selman Ozdan, 'Immunity vs. Impunity in International Law: A Human Rights Approach' (2018) 4 Baku State University Law Review 36, 52.

3 ibid 42. See also generally Jacques Fomerand, Historical Dictionary of Human Rights (Rowman \& Littlefield 2014); Kingsley Chiedu Moghalu, 'Reconciling Fractured Societies: An African Perspective on the Role of Judicial Prosecutions’ in Ramesh Chandra Thakur and Petrus Adrianus Maria Malcontent (eds), From Sovereign Impunity to International Accountability: The Search for Justice in a World of States (United Nations University Press 2004).

${ }^{4}$ Human rights recognised as peremptory norms includes the prohibitions against slavery or slave trade; genocide; torture or other cruel, inhuman, or degrading treatment or punishment; murder or disappearance of individuals; systematic racial discrimination; prolonged arbitrary detention; and the principles of the United Nations Charter prohibiting the use of force. See Yousuf v Samantar (2012) 699 F 3d 763 (Court of Appeals, 4th Circuit) 775-76; Evan J Criddle and Evan Fox-Decent, 'A Fiduciary Theory of Jus Cogens' (2009) 34 Yale Journal of International Law 331.
} 


\section{DEVELOPMENTS OF HEAD OF STATE IMMUNITY IN INTERNATIONAL LEGAL SYSTEM}

The concept of Head of State immunity was explicitly and conceptually located in the 1987 In re Grand Jury Proceedings, Doe No. 770, in which the US Court of Appeals for the Fourth Circuit stated that Head of State immunity 'is a doctrine of customary international law. Generally speaking, the doctrine maintains that a head of state is immune from the jurisdiction of a foreign state's courts, at least as to authorised official acts taken while the ruler is in power'. ${ }^{5}$

In simple terms, the principle of immunity has been instituted to protect a State and its senior officials from being sued before its courts and particularly foreign courts, so that they can carry out their activities abroad without impediment. Since immunity from prosecution and execution is based upon the sovereign equality principle of States, this principle does not prevent senior State officials from being indicted before an international court as long as this court is vested in jurisdiction over serving or former Heads of State. ${ }^{6}$

Prior to 1919, there was little discussion of immunity for Heads of State before international tribunals or courts, as the issue had been all but taboo with regard to any waiver of such immunity. However, the Versailles Treaty, which is generally accepted as the first indictment of a former Head of State before an international tribunal, is seen by many as breaking this taboo. On this point, Article 227 of the Treaty reads as follows:

The Allied and Associated Powers publicly arraign William II of Hohenzollern [The Kaiser], formerly German Emperor, for a supreme offence against international morality and the sanctity of treaties. A special tribunal will be constituted to try the accused, thereby assuring him the guarantees essential to the rights of defence. It will be composed of five judges, one appointed by each of the following powers: namely, the United States of America, Great Britain, France, Italy and Japan. In its decision the tribunal will be guided by the highest motives of international policy, with a view to vindicating the solemn obligations of international undertakings and the validity of international morality. It will be its duty to fix the punishment which it considers should be imposed. The Allied and Associated Powers will address a request to the Government of the Netherlands for the surrender to them of the ex-Emperor in order that he may be put on trial. ${ }^{7}$

\footnotetext{
${ }^{5}$ In re Grand Jury Proceedings [1987] United States Court of Appeals, Fourth Circuit 700, 1108 817 F2d 1111. For a private visit to another State, Sir Arthur Watts stated that although 'it may well be that a Head of State, when on a private visit to another State, still enjoys certain privileges and immunities, it is much less likely that the same is true of heads of governments and foreign ministers. Although they may be accorded certain special treatment by the host State, this is more likely to be a matter of courtesy and respect for the seniority of the visitor, than a reflection of any belief that such a treatment is required by international law'. Sir Arthur Watts, The Legal Position in International Law of Heads of States, Heads of Governments and Foreign Ministers, vol 247 (Martinus Nijhoff Publishers 1994) 109.

${ }^{6}$ Brigitte Stern, 'Immunities for Heads of State: Where Do We Stand?' in Mark Lattimer and Philippe Sands (eds), Justice for Crimes Against Humanity (Hart Publishing 2003).

${ }^{7}$ Peace Treaty of Versailles 1919 Article 227.
} 
However, the Kaiser was never tried. Before Armistice Day, the Kaiser fled to the Netherlands and asylum was granted to him by the Dutch government who refused to hand him over for trial. ${ }^{8}$ After the Treaty of Versailles, the issue of immunity for Heads of State was challenged through the Statutes of the Nuremberg and Tokyo international military tribunals. Article 7 of the Charter of the Nuremberg Tribunal declared that the 'official position of defendants, whether heads of state or responsible officials in Government Departments, shall not be considered as freeing them from responsibility or mitigating punishment'. ${ }^{9}$ A number of significant developments in international law have taken place whose outcome has been to restrict Head of State immunity in the interest of securing and maintaining fundamental human rights. The Nuremberg Principles include the assertion that the 'fact that a person who committed an act which constitutes a crime under international law acted as Head of State or responsible Government official does not relieve him from responsibility under international law' ${ }^{10}$ In a similar vein, Article 6 of the Statute of the Tokyo Tribunal declared that:

Neither the official position, at any time, of an accused, nor the fact that an accused acted pursuant to order of his government or of a superior shall, of itself, be sufficient to free such accused from responsibility for any crime with which he is charged. ${ }^{11}$

In respect of both statements by international military tribunals, international law unequivocally protects State officials and provides immunity; however, in particular circumstances immunity for Heads of State cannot be invoked if his or her deeds constitute a violation of fundamental human rights. If violations of those human rights are at stake, the official position of a Head of State should not serve as a shield to avoid punishment. Immunity should apply only to sovereign acts; therefore, Heads of State should not enjoy functional immunity in relation to violations of fundamental human rights. Functional immunity provides protection for sovereign acts; however, acts which cause fundamental human rights violations should not be deemed as sovereign acts. ${ }^{12}$

Concerning individual criminal responsibility, it is clear that the statutes of the International Criminal Tribunal for the Former Yugoslavia and the International Criminal Tribunal for Rwanda are considered important developments in terms of clarifying the position of Head of State immunity in relation to international crimes that give rise to fundamental human rights violations. Both statutes emphasise that Heads of State should not benefit from immunity. Article $7(2)$ of the Statute of the International Criminal Tribunal for the Former Yugoslavia provides that the 'official position of any accused

\footnotetext{
${ }^{8}$ See Gary D Solis, The Law of Armed Conflict: International Humanitarian Law in War (Cambridge University Press 2010) 74.

9 'Nuremberg Trial Proceedings Vol. 1 - Charter of the International Military Tribunal' Article 7.

10 'Principles of International Law Recognized in the Charter of the Nuremberg Tribunal and in the Judgment of the Tribunal, 5 UN GAOR Supp. (No. 12) at 11, U.N. Doc. A/1316' Principle 3.

11 'International Military Tribunal for the Far East Charter' (1946) Article 6.

12 RA Kolodkin, 'Second Report on Immunity of State Officials from Foreign Criminal Jurisdiction, 62nd Session’ (International Law Commission 2010) UN Doc. A/CN.4/631 para 28, 29, 30 and 31; Dapo Akande and Sangeeta Shah, 'Immunities of State Officials, International Crimes, and Foreign Domestic Courts' (2010) 21 European Journal of International Law 815.
} 
person, whether as Head of State or Government or as a responsible Government official, shall not relieve such person of criminal responsibility nor mitigate punishment'. ${ }^{13}$ Article 6(2) of the Statute of the International Criminal Tribunal for Rwanda reiterates this statement. In so doing, this provision acknowledges that perpetrators of human rights violations, regardless of their official position, cannot hide behind the shield of immunity; and that Heads of State enjoy no impunity. Furthermore, in the case of Prosecutor $v$ Blaskic, the Appeal Chamber of the Yugoslavia Tribunal highlighted that:

The general rule under discussion is well established in international law and is based on the sovereign equality of States (par in parem non habet imperium). The few exceptions relate to one particular consequence of the rule. These exceptions arise from the norms of international criminal law prohibiting war crimes, crimes against humanity and genocide. Under these norms, those responsible for such crimes cannot invoke immunity from national or international jurisdiction even if they perpetrated such crimes while acting in their official capacity. ${ }^{14}$

In a similar vein, Article 27 of the Rome Statute embodies provisions which indicate that the Statute applies to all individuals regardless of their official position within a State:

This Statute shall apply equally to all persons without any distinction based on official capacity. In particular, official capacity as a Head of State or Government, a member of a Government or parliament, an elected representative or a government official shall in no case exempt a person from criminal responsibility under this Statute, nor shall it, in and of itself, constitute a ground for reduction of sentence.

Immunities or special procedural rules which may attach to the official capacity of a person, whether under national or international law, shall not bar the Court from exercising its jurisdiction over such a person. ${ }^{15}$

The essential purpose of the incorporation of these provisions into the Rome Statute and ad hoc tribunals is to ensure individual criminal responsibility for all persons, and particularly Heads of State, who perpetrate violations of fundamental human rights which constitute international crimes. Furthermore, by ensuring individual criminal responsibility, those provisions prevent certain persons from using their official position as a shield against prosecution for those human rights violations.

Article 98(1) of the Statute of the International Criminal Court goes beyond States party to the Statute. Article 98(1), which is concerned with cooperation with respect to the waiver of immunity and consent to surrender, reads as follows:

\footnotetext{
${ }^{13}$ UN Security Council, Statute of the International Criminal Tribunal for the Former Yugoslavia, SC res. 827, UN SCOR 48th sess., 3217th mtg. at 1-2 1993 Article 7(2).

${ }^{14}$ Prosecutor $v$ Tihomir Blaskic [1997] 110 ILR 687 (International Criminal Tribunal for the Former Yugoslavia) 710.

15 'Rome Statute of the International Criminal Court' (UN General Assembly 2002) Article 27(1),(2).
} 
The Court may not proceed with a request for surrender or assistance which would require the requested State to act inconsistently with its obligations under international law with respect to the State or diplomatic immunity of a person or property of a third State, unless the Court can first obtain the cooperation of that third State for the waiver of the immunity. ${ }^{16}$

Articles 27 and 98(1) of the Rome Statute might be seen as contradictory in that the former rejects immunities while the latter endorses immunities. However, article 98(1) addresses a particular situation in which a State party to the Statute is required to surrender a person who is jurisdictionally untouchable by virtue of the immunities granted by a third State. In this sense, this case can be described as an equation with three knowns (a State Party, the Statute, and a person endowed with immunities), although it would appear that the equation always produces a tangled outcome for the State to whom the request is made. Specifically, the State Party to the Statute either must breach its obligation to meet the requirements of the Court or must breach its commitment to abide by immunities of a State that is not party to the Statute. The interaction between Articles 27 and 98(1) of the Statute thereby establishes a system wherein the State Parties to the Statute consent to surrender all immunity rights in relation to the Court's requirements regarding their own State officials or representatives, while still abiding by the immunities of States that are not yet party to the Statute. ${ }^{17}$

Ultimately, Article 98(1) of the Statute implies three situations where the immunities bestowed on a person by a State that is not a party to the Statute can be trumped. First, if a State that is not a party to the Statute agrees to relinquish the immunity, the person can be prosecuted. Second, if the State official is no longer in office, the official's personal immunity ends (although functional immunity can still be enjoyed), thus enabling the official to be prosecuted for committed violations of human rights. Third, if the United Nations Security Council requests full participation under Chapter VII, the State which is not a party to the Statute automatically is deprived of its immunity rights, and must surrender the accused. ${ }^{18}$

\footnotetext{
16 ibid Article 98(1).

17 See for detailed analyses on the interplay of Articles 27 and 98(1) of the International Criminal Court Statute Paola Gaeta, 'Official Capacity and Immunities' in Antonio Cassese, Paola Gaeta and John RWD Jones (eds), The Rome Statute of the International Criminal Court: A Commentary, vol I (Oxford University Press 2002); Dapo Akande, 'The Legal Nature of Security Council Referrals to the ICC and Its Impact on Al Bashir’s Immunities’ (2009) 7 Journal of International Criminal Justice 333.

18 Robert Cryer and others, An Introduction to International Criminal Law and Procedure (2nd edn, Cambridge University Press 2010) 556. For the relationship between the International Criminal Court and UN Security Council with regards to the issue of waiving immunity, see Akande (n 17); Cryer and others 549-557.
} 


\section{The Problem of Head of State ImMunity in Relation to Violations of Human Rights ReCOGNISEd AS PEREMPTORY NORMS}

In international law, a number of prominent decisions have bearing on the tension between vesting immunity in the Head of State and the protection of human rights recognised as peremptory norms. ${ }^{19}$ In analysing Head of State immunity in the context of human rights violations, the Arrest Warrant of 11 April 2000 (Democratic Republic of the Congo v Belgium) case is important, particularly in relation to the question of whether or not Head of State immunity equates to Head of State impunity in such cases. Heads of State sometimes enjoy considerable leeway to escape from proceedings in respect of human rights violations. In this sense, the concept of immunity is sometimes 'wrongfully utilised to signify that a person benefits from impunity or is not prosecuted, for reasons other than the technical legal bar of immunity'. ${ }^{20}$

That said, the perspective of the International Court of Justice for Mr Yerodia raises the issue of immunity or impunity for Heads of State when violations of fundamental human rights are perpetrated. In the Arrest Warrant case, Belgium argued that immunities accorded to incumbent Foreign Affairs Ministers cannot, under any circumstances, provide the minister with protection where he or she is suspected of having perpetrated violations of fundamental human rights. Subsequently, Belgium touched upon the question of whether a person's high-level status within a State constitutes an impediment to prosecution. On this point, Belgium claimed that the official position of a person should not be an obstacle to applying jurisdiction. On 11 April 2000, an international arrest warrant was issued by a Belgian investigating judge of the Brussels Tribunal of First Instance against Abdulaye Yerodia Ndombasi, the Minister for Foreign Affairs of the Democratic Republic of the Congo (DRC), in respect of alleged crimes against humanity and violations of international humanitarian law. Mr Yerodia was accused of having made some speeches that incited racial hatred and occasioned the massacre of Tutsi civilians in 1998. Mr Yerodia was charged by the Belgian judge with grave breaches of the International Geneva Conventions of 1949 and of their Additional Protocols I and II of 1977. The arrest warrant for Mr Yerodia was transferred to the Democratic Republic of the Congo and concurrently circulated at the international level

\footnotetext{
${ }^{19}$ Strictly speaking, the suit against the former President of Chile Augusto Pinochet by the UK House of Lords in 1998 and 1999 was a significant in international law as Pinochet could not claim immunity for acts of torture for which he was responsible. Although it might have been ruled on narrow grounds, this important decision appears to have marked the end of immunity in cases involving violations of fundamental human rights by a former Head of State, even when those violations were committed while the Head of State was in office. Michael Tunks, 'Diplomats or Defendants? Defining the Future of Headof-State Immunity’ (2002) 52 Duke Law Journal 651, 659; Ingrid Wuerth, 'Pinochet’s Legacy Reassessed’ (2012) 106 The American Journal of International Law 731; see Charles Pierson, 'Pinochet and the End of Immunity: England's House of Lords Holds That a Former Head of State Is Not Immune for Torture’ (2000) 14 Temple International and Comparative Law Journal 263. For the Pinochet decision see $R v$ Bow Street Metropolitan Stipendiary Magistrate and Others, ex parte Pinochet Ugarte (No 1) (1998) 4 AII ER (House of Lords); $R v$ Bow Street Metropolitan Stipendiary Magistrate and Others, ex parte Pinochet Ugarte (No 2) (1999) 2 W.L.R. 272 (House of Lords); $R v$ Bow Street Metropolitan Stipendiary Magistrate and Others, ex parte Pinochet Ugarte (No 3) (2000) 1 A.C. 147 (House of Lords).

${ }^{20}$ Stern (n 6) 81.
} 
via Interpol. Ultimately, Belgian authorities brought a suit against Mr Yerodia based on the Belgian Law of 16 June 1993, concerning the punishment of grave breaches of the Geneva Conventions and their Additional Protocols, which provides a basis for universal jurisdiction in regard to such violations. Article 5(3) of the Belgian Law also provides that the immunity enjoyed by a person who acts in an official capacity does not create any obstacle to the application of the law. ${ }^{21}$

On 17 October 2000, the Democratic Republic of the Congo filed an application with the International Court of Justice instituting proceedings against the Belgian Kingdom in relation to the case involving this international arrest warrant. In making the Application, the Democratic Republic of the Congo relied on two legal grounds. First, the Democratic Republic of the Congo asserted that Belgium had violated its obligation to respect the immunity of the Minister of Foreign Affairs of a sovereign State. Second, the Democratic Republic of the Congo alleged that Belgium had breached the principle that a State cannot exercise its authority over another State's territory and the principle of sovereign equality of States. On this point, the Democratic Republic of the Congo claimed that the 'universal jurisdiction that the Belgian State attributes to itself under Article 7 of the law in question' does not comply with the principle of sovereign equality. The heart and soul of the argument of the Democratic Republic of the Congo concerned the violation of customary international rule in relation to the absolute immunity and inviolability of incumbent Foreign Ministers from criminal jurisdiction. Arguing that Belgium had infringed the sovereign equality principle of States, the Democratic Republic of the Congo requested that the International Court of Justice require Belgium to declare its international arrest warrant null and void. ${ }^{22}$ The Democratic Republic of the Congo insisted that Belgium had no jurisdiction under international law to issue and circulate an international arrest warrant, and that by doing so it had breached the rights of the Democratic Republic of the Congo to perform and conduct its foreign affairs through its foreign minister. ${ }^{23}$

Belgium pointed to the decision rendered on 24 March 1999 by the House of Lords in the United Kingdom in relation to the former head of State of Chile, General Augusto Pinochet Duarte, which recognised and accepted an exception to the principle of immunity in respect of violations of fundamental human rights under international law.

\footnotetext{
${ }^{21}$ See the Judgment of Arrest Warrant of 11 April 2000 (Democratic Republic of the Congo $v$ Belgium) (2002) I.C.J. Reports; See generally Matthias Goldmann, 'Arrest Warrant Case (Democratic Republic of the Congo v Belgium)', Max Planck Encyclopedia of Public International Law (MPEPIL) (Oxford University Press 2009); see for the mentioned article Belgium: Act of 1999 Concerning the Punishment of Grave Breaches of International Humanitarian Law 1999.

${ }^{22}$ See Arrest Warrant of 11 April 2000 (Democratic Republic of the Congo v. Belgium) (n 21) [1, 21, and 62]. Article 7 of the Act of 1999 Concerning the Punishment of Grave Breaches of International Humanitarian Law is about competence, applicable procedure and the execution of sentences. It states that the 'Belgian courts shall be competent to deal with breaches provided for in the present Act, irrespective of where such breaches have been committed'. Belgium: Act of 1999 Concerning the Punishment of Grave Breaches of International Humanitarian Law (n 21).

${ }^{23}$ Arrest Warrant of 11 April 2000 (Democratic Republic of the Congo v. Belgium) (n 21); see also Alexander Orakhelashvili, 'Arrest Warrant of 11 April 2000 (Democratic Republic of the Congo v. Belgium)’ (2002) 96 American Journal of International Law 677.
} 
According to Belgium, the holding in the Pinochet No 3 case advanced the development of international law by acknowledging an important exception to the principle of immunity for Heads of State or Government. ${ }^{24}$ Belgium accordingly referred to a statement by Lord Millett that international law 'cannot be supposed to have established a crime having the character of a jus cogens and at the same time to have provided an immunity which is co-extensive with the obligation it seeks to impose'. Belgium also cited the words of Lord Phillips of Worth Matravers that 'no established rule of international law requires state immunity ratione materiae to be accorded in respect of prosecution for an international crime'. ${ }^{25}$

The Democratic Republic of the Congo, following Belgium's argument concerning the Pinochet decision, emphasised that according to international law as it currently stands, there was no basis for any exception to the principle of Head of State immunity from criminal jurisdiction for a standing Minister of Foreign Affairs where she or he is accused of having perpetrated fundamental human rights violations under international law. The Democratic Republic of the Congo, by cross-referencing the Pinochet decision, emphasised Lord Browne-Wilkinson's statement that this 'immunity enjoyed by a head of state in power and an ambassador in post is a complete immunity attached to the person of the head of state or ambassador and rendering him immune from all actions or prosecutions whether or not they relate to matters done for the benefit of the state'. ${ }^{26}$ Here, the focus is on whether the accused is an incumbent or a former Head of State rather than the gravity of their alleged crimes. The Democratic Republic of the Congo argued that the immunity 'accorded to Ministers for Foreign Affairs when in office covers all their acts, including any committed before they took office, and that it is irrelevant whether the acts done whilst in office may be characterized or not as official acts'. ${ }^{27}$

The International Court of Justice examined the decision of the House of Lords in the Pinochet case but found that there was no applicable exception to the rule of Head of State immunity from criminal jurisdiction; moreover, it found that current Ministers of Foreign Affairs are particularly inviolable where they are suspected of having perpetrated violations of fundamental human rights. Accordingly, the Court rejected the Belgian argument in relation to the Pinochet decision by the House of Lords. ${ }^{28}$

Belgium's approach in the Democratic Republic of the Congo v Belgium case can be regarded as an important step towards the objective of abolishing impunity for perpetrators of fundamental human rights violations. On this point, Belgium pointed out that:

\footnotetext{
${ }^{24}$ Arrest Warrant of 11 April 2000 (Democratic Republic of the Congo v. Belgium) (n 21) [56].

${ }^{25} \mathrm{R} v$. Bow Street Metropolitan Stipendiary Magistrate and Others, ex parte Pinochet Ugarte (No. 3) (n 19) 278 and 289; see also Reed Brody and Michael Ratner (eds), The Pinochet Papers: The Case of Augusto Pinochet Ugarte in Spain and Britain (Kluwer Law International 2000) 346.

${ }^{26} R$ v. Bow Street Metropolitan Stipendiary Magistrate and Others, ex parte Pinochet Ugarte (No. 3) (n 19) 201-202.

${ }^{27}$ Arrest Warrant of 11 April 2000 (Democratic Republic of the Congo v. Belgium) (n 21) [47].

28 ibid 58-59.
} 
[W]hile Ministers for Foreign Affairs in office generally enjoy an immunity from jurisdiction before the courts of a foreign State, such immunity applies only to acts carried out in the course of their official functions, and cannot protect such persons in respect of private acts or when acting otherwise than in the performance of their official functions. ${ }^{29}$

The International Court of Justice stated that it is bound 'to find that, given the nature and purpose of the warrant, its mere issue violated the immunity which Mr Yerodia enjoyed as the [Democratic Republic of] the Congo's incumbent Minister for Foreign Affairs'. The Court therefore decided that the warrant issue led to a violation of Belgium's obligation towards the Democratic Republic of the Congo, in that Belgium failed to respect Head of State immunity. According to the Court, Belgium also breached the immunity from criminal jurisdiction under international law. ${ }^{30}$ It follows that the principle of immunity for an incumbent Head of State is still prevalent and alive, even in respect of violations of fundamental human rights prohibited under international law. In respect of the distinction between immunity and impunity bestowed on Heads of State, the International Court of Justice underscored that the immunity from jurisdiction enjoyed by Heads of State in power does not mean that they can benefit from impunity with reference to any violations they may have perpetrated, regardless of their seriousness. 'Immunity from criminal jurisdiction and individual criminal responsibility are quite separate concepts. While jurisdictional immunity is procedural in nature, criminal responsibility is a question of substantive law'. The Court added that while jurisdictional immunity may become an obstacle to prosecution for definite offences or for a definite period, 'it cannot exonerate the person to whom it applies from all criminal responsibility'. ${ }^{31}$

The Court implied that the immunities provided by international law for a current or former Head of State do not constitute an impediment to criminal prosecution in particular circumstances. Subsequently, the Court observed four exceptional situations to Head of State immunity under international law. Although the judgment of the International Court of Justice implied that the immunity from jurisdiction enjoyed by Heads of State does not equate to impunity for international crimes, the exceptions to Head of State immunity outlined by the Court become insufficient to abolish impunity.

First, the Court stated that a Head of State does not enjoy immunity under international law from criminal proceedings in his/her own country's courts. Second, the Court held that Heads of State should be deprived of jurisdictional immunity before a foreign State's court if the State which they represent waives their immunity rights. ${ }^{32}$

Regarding the aforementioned two exceptional situations, prosecution requires 'a willingness of the State which appointed the person as a Foreign Minister to investigate and prosecute allegations against him domestically or to lift immunity in order to allow

\footnotetext{
29 ibid 49.

30 ibid 70 .

31 ibid 60 .

32 ibid 61; for further analysis see Stern (n 6).
} 
another State to do the same'. ${ }^{33}$ Be that as it may, where domestic authorised bodies do not consent to open an investigation or start a prosecution, the committed violations of human rights will go unpunished. Such an outcome raises the issue of impunity.

The third exception the Court identified was that after a person's official position as a Minister for Foreign Affairs ends, he or she can no longer benefit from the immunities granted by international law in foreign States. 'Provided that it has jurisdiction under international law, a court of one State may try a former Minister for Foreign Affairs of another State in respect of acts committed prior or subsequent to his or her period of office, as well as in respect of acts committed during that period of office in a private capacity'. ${ }^{34}$

The last exception identified by the Court was that neither former nor incumbent Heads of State enjoy immunity when that immunity has been limited by a treaty establishing an international court. Afterwards, the International Court of Justice listed the International Criminal Court as one such tribunal which may overturn the immunity of a Head of State provided that it has jurisdiction under international law. ${ }^{35}$ The jurisdiction of the Court arises from the authority vested by the contracting States in the Statute of the Court or via the United Nations Security Council. As Michael Tunks noted, 'no other country has jurisdiction over a third party's head of state, and, consequently, no two states may agree by treaty to waive the immunity of a third party's head of state without that other nation's consent'. ${ }^{36}$ It follows that the alleged jurisdiction of the court's statute over a Head of State whose home State does not assent to the statute is not sufficient to rectify customary international law and protect fundamental human rights from Head of State impunity.

It would be untenable to claim that in the absence of the International Criminal Court, a Head of State who is suspected of having committed violations of fundamental human rights would be justiciable solely before his or her own State's courts.

\section{Protection of Fundamental human Rights VS. Head of State}

\section{IMPUNITY}

With respect to the peremptory nature of fundamental human rights, the decision by the International Court of Justice offers no clear or plain solution to the tension between Head of State immunity and protection of fundamental human rights. The

\footnotetext{
${ }^{33}$ Arrest Warrant of 11 April 2000 (Democratic Republic of the Congo v. Belgium) (n 21) [35] [Dissenting Opinion of Judge Van den Wyngaert].

34 ibid 61; see for comments on the third exception of the Court Antonio Cassese, 'When May Senior State Officials Be Tried for International Crimes? Some Comments on the Congo v. Belgium Case’ (2002) 13 European Journal of International Law 853, 867-68.

${ }^{35}$ Arrest Warrant of 11 April 2000 (Democratic Republic of the Congo v. Belgium) (n 21) [61].

${ }^{36}$ See Tunks (n 19) 665; see also generally Madeline Morris, 'The Democratic Dilemma of the International Criminal Court' (2002) 5 Buffalo Criminal Law Review 591; see generally Cassese (n 34). 'The International Criminal Court will only be able to act if States which have jurisdiction are unwilling or unable genuinely to carry out investigation or prosecution'. Arrest Warrant of 11 April 2000 (Democratic Republic of the Congo v. Belgium) (n 21) [37] [Dissenting Opinion of Judge Van den Wyngaert].
} 
Judgment undermined the argument that the principle of protection of fundamental human rights becomes hierarchically superior to immunity norms; if it were, immunity would be obtainable neither by States nor by current or former Heads of State. ${ }^{37}$

In the Democratic Republic of the Congo $v$ Belgium case, Judge ad hoc Van den Wyngaert, in her Dissenting Opinion, claimed that there were no grounds in positive international law for bestowing full immunity on incumbent Heads of State against foreign criminal jurisdiction. She emphasised that neither State practice nor opinio juris constitutes an international custom that affects the Court's decision. ${ }^{38}$ It follows that there is no treaty or legal opinion that supports the proposition of the Court. International law does not provide immunity to incumbent Heads of State from criminal proceedings when they perpetrate violations of fundamental human rights. In this sense, Belgium's act might seem to be at odds with international comity; however that act did not breach an international legal obligation. Judge Wyngaert then stated that:

[T[he Court's conclusion is reached without regard to the general tendency toward the restriction of immunity of the State officials (including even Heads of State), not only in the field of private and commercial law where the par in parem principle has become more and more restricted and deprived of its mystique, but also in the field of criminal law, when there are allegations of serious international crimes. ${ }^{39}$

It must be noted that the international arrest warrant was issued by Belgium in respect of accusations of war crimes which the International Court of Justice failed to mention. It is important to ask what is required under international law and what international law permits States, as members of international society, to do when their officials are accused of violations of fundamental human rights. In this sense, two particular interests are reflected in contemporary international law: first, the demand for international accountability for having allegedly committed violations of fundamental human rights and second, the sovereign equality principle of States which is regarded as a prerequisite for immunities. ${ }^{40}$

Redressing the balance between these two particular interests is important for resolving the contradiction between Head of State immunity and protection of fundamental human rights. The Court, instead of redressing the balance, considered a very narrow question on the immunities of incumbent Ministers of Foreign Affairs. By doing so, the Court 'has missed an excellent opportunity to contribute to the development of modern international criminal law' ${ }^{41}$

\footnotetext{
37 See Wuerth (n 19) 741.

${ }^{38}$ Arrest Warrant of 11 April 2000 (Democratic Republic of the Congo v. Belgium) (n 21) [1, 10, and 23] [Dissenting Opinion of Judge Van den Wyngaert]; see also Petra Minnerop and others, World Court Digest 2001 - 2005, vol 4 (Springer Science \& Business Media 2009).

${ }^{39}$ Arrest Warrant of 11 April 2000 (Democratic Republic of the Congo v. Belgium) (n 21) [23] [Dissenting Opinion of Judge Van den Wyngaert].

40 ibid 5 [Dissenting Opinion of Judge Van den Wyngaert].

${ }^{41}$ ibid 6 [Dissenting Opinion of Judge Van den Wyngaert].
} 
The International Court of Justice, in the Arrest Warrant case, recognised that a former and incumbent Foreign Affairs Minister 'might be subject to criminal proceedings before certain international criminal courts where they have jurisdiction'. ${ }^{42}$ The Court specifically cited the International Criminal Court as an example.

This issue was indeed raised before the International Criminal Court in respect of an arrest warrant for the incumbent President of the Sudan, Omar Hassan Ahmad AlBashir. When, on 4 March 2009 and 12 July 2010, Pre-Trial Chamber I of the International Criminal Court issued two warrants of arrest for Omar al Bashir for crimes against humanity and war crimes, his arrest was required in accordance with the Rome Statute. ${ }^{43}$ Omar Al-Bashir was suspected of being criminally responsible as an indirect violator, or co-perpetrator, for the liable person in respect of the crime of genocide. ${ }^{44}$ Since the arrest warrants were issued, President Al-Bashir has travelled to several countries, including the Republic of Kenya, Djibouti, Malawi, the Republic of Chad, South Africa. Although those countries are State parties to the Rome Statute and hence were obligated to arrest him, he has never been arrested. ${ }^{45}$

On 15 February 2013, Pre-Trial Chamber II of the Court 'requested the Registry to send Notes Verbales to the Republic of Chad and the State of Libya, enquiring about said visit, and reminding the former of its obligations with respect to the arrest and surrender of Omar Al-Bashir to the Court'. Al Bashir travelled to Chad to attend a summit and departed from Chad; however, the Chadian Government took no measure to arrest him. The international community called on Chad to abide by the obligations decided upon by the Court regarding the arrest warrant for Al Bashir and the Government of Chad was required to provide information to the Chamber about Al Bashir's alleged journey. On 26 March 2013, Pre-Trial Chamber II issued that Chad had failed to cooperate with the International Criminal Court and indicated the non-compliance of Chad to the obligations of the Security Council. ${ }^{46}$ Al-Bashir also attended the African Union summit scheduled from 7 to 15 June 2015 in South Africa. On 13 June 2015, Pre-Trial Chamber II asserted that the Republic of South Africa had an obligation to arrest and surrender AlBashir. South Africa failed to arrest him. On 15 October 2015, upon South Africa's request, Pre-Trial Chamber II extended the deadline to submit a report regarding the failure of the South African Government to arrest Al-Bashir. ${ }^{47}$

In respect of the jurisdiction, the Pre-Trial Chamber declared that the official position of Al-Bashir as Head of State did not free him from appearing before the

\footnotetext{
${ }^{42}$ Fox QC and Webb (n 1) 558.

43 The Prosecutor v Al Bashir, First Arrest Warrant [2009] ICC-02/05-01/09 (Pre-Trial Chamber I); The Prosecutor v Al Bashir, Second Arrest Warrant [2010] ICC-02/05-01/09-95 (Pre-Trial Chamber I); 'Rome Statute of the International Criminal Court' (n 15) Article 58(1)(b).

${ }^{44}$ The Prosecutor v Al Bashir, Second Arrest Warrant (n 43).

${ }^{45}$ Some non-State parties to the Rome Statute were also welcomed Omar Al-Bashir: The Islamic Republic of Mauritania, the People's Republic of China, People’s Democratic Republic of Algeria, and the Arab Republic of Egypt. See 'Bashir-Watch’ <http://bashirwatch.org/> accessed 05 July 2018.

46 The Prosecutor v Omar Al Bashir (2013) ICC-02/05-01/09-151 (Pre-Trial Chamber II).

47 The Prosecutor v Omar Al Bashir (2015) ICC-02/05-01/09-242 (Pre-Trial Chamber II).
} 
International Criminal Court. The Chamber proposed four considerations in reaching this decision. First, the Chamber emphasised that one of the crucial goals of the Rome Statute is to end impunity for perpetrators of violations of international crimes which amount to human rights violations. Second, the Chamber noted that Article 27 of the Statute must be applied to achieve this goal. This provision makes immunity non-applicable and enforces the criminal responsibility of all persons regardless of their official capacity in a State. Third, as required by Article 21 of the Rome Statute, other sources of law can be applied only if there is a gap in the Rome Statute that cannot be filled by interpreting the Vienna Convention on the Law of the Treaties with respect to internationally accepted human rights norms. Fourth, the United Nations Security Council has accepted that the investigation into the situation in Sudan and any prosecution generated therefrom will be compatible with the Statutory framework of the International Court of Justice. ${ }^{48}$ On this point, Dapo Akande stated that 'the nature of the Charter as a sort of constitutional document, and [...] obligations under the Charter ought to be regarded as taking priority over the customary international law' ${ }^{49}$

Sudan is not a state party to the Rome Statute; however, the United Nations Security Council, in referring the case in Darfur to the International Criminal Court, made reference to Article 13(b) of the Statute. Subsequently, the Council required that Sudan should co-operate with the Court. ${ }^{50}$ Under Chapter VII of the United Nations Charter, the Security Council possesses full authority to take measures in order to contribute to the maintenance of international peace and to maintain and restore international security. By becoming a member of the United Nations, the Sudanese Government gives implicit consent to the Security Council for the abolition of Head of State immunity, because Article 25 of the Charter requires Member States to accept and execute the decisions of the Council. It follows that immunity for Al-Bashir before the courts of foreign States has been implicitly abolished. It must be noted that abolishing immunity in relation to the accusations in the Al-Bashir case conforms with the Security Council's objective, which is to avoid absolute impunity for perpetrators of fundamental human rights violations that pose a threat to international security and peace. ${ }^{51}$

International law does not prohibit investigation of alleged violations of human rights; in fact, international law supports such inquiries, even if the accused perpetrator

\footnotetext{
${ }^{48}$ See The Prosecutor v Al Bashir, First Arrest Warrant (n 43) at paras. 41, 42, 43, 44 and 45; see also Jessica Needham, 'Protection or Prosecution for Omar Al Bashir? The Changing State of Immunity in International Criminal Law’ (2011) 17 Auckland University Law Review 219.

49 Akande (n 17) 348.

${ }^{50}$ Needham (n 48) 247.

${ }^{51}$ See generally Sophie Papillon, ‘Has the United Nations Security Council Implicitly Removed Al Bashir’s Immunity?' (2010) 10(2) International Criminal Law Review 275. There is another perspective that claims that the implicit removal of immunity by the Security Council would be at odds with customary international law and treaty principles which provide immunity for serving heads of State. Be that as it may, Article 103 of the United Nations Charter reports that in 'the event of a conflict between the obligations of the Member of the United Nations under the present Charter and their obligations under any other international agreement, their obligations under the present Charter shall prevail'. For a critique of the implicit removal of immunity by the Council see Paola Gaeta, 'Does President Al Bashir Enjoy Immunity from Arrest?’ (2009) 7 Journal of International Criminal Justice 315.
} 
committed the crime as a State agent in a foreign State. ${ }^{52}$ This is evident in the history of international law, in which there are very significant codifications of the principle of individual accountability for violations of fundamental human rights. For example, the 1950 Nuremberg Principles highlighted that 'any person who commits an act which constitutes a crime under international law is responsible therefor and liable to punishment'. ${ }^{53}$ Likewise, Article 4 of the Convention on the Prevention and Punishment of the Crime of Genocide reads as follows: 'Persons committing genocide or any of the other acts enumerated in Article 3 shall be punished, whether they are constitutionally responsible rulers, public officials or private individuals'.${ }^{54}$ Furthermore, official reports and resolutions can be found under the United Nations. ${ }^{55}$

Prioritising the immunities for Heads of State in cases involving violations of fundamental human rights produces a tension between the immunity principle and the protection of those human rights. That is to say, the prohibitions against certain violations of human rights are deemed as jus cogens in nature, and since jus cogens norms are in no case trumped by any other norm, the hierarchy should be established by considering the superiority of jus cogens norms. It follows that the protection of fundamental human rights takes priority under international law. On this point, it must be noted that where violations of fundamental human rights 'are concerned, immunity cannot block investigations or prosecutions [of] such [violations], regardless of whether such proceedings are brought before national or before international courts' ${ }^{56}$ To protect and improve the fundamental values and interests of human beings, the effective prohibition of certain violations of human rights has been recognised by the international community as having a jus cogens character. It follows that, if this hierarchically superior norm becomes at variance with the principles guiding Head of State immunity, it should be trumped by those provisions which are designed to defend and maintain fundamental human rights. ${ }^{57}$

\footnotetext{
${ }^{52}$ Arrest Warrant of 11 April 2000 (Democratic Republic of the Congo v. Belgium) (n 21) [Dissenting Opinion of Judge Van den Wyngaert].

53 'Principles of International Law Recognized in the Charter of the Nuremberg Tribunal and in the Judgment of the Tribunal, 5 UN GAOR Supp. (No. 12) at 11, U.N. Doc. A/1316' (n 12) Principle 1.

54 'Convention on the Prevention and Punishment of the Crime of Genocide Adopted by General Assembly of the United Nations' (United Nations Treaty Series 1948) 78. The acts listed in Article 3 are genocide, conspiracy to commit genocide, direct and public incitement to commit genocide, attempt to commit genocide and complicity in genocide.

${ }^{55}$ See for example United Nations Commission on Human Rights, 'The Administration of Justice and the Human Rights of Detainees, Question of the Impunity of Perpetrators of Human Rights Violations (Civil and Political) Revised Final Report Prepared by Mr. Joinet pursuant to Sub-Commission Decision 1996/119' (1997) UN Doc. E/CN.4/Sub.2/1997/20/Rev.1; United Nations Commission on Human Rights, 'Promotion and Protection of Human Rights: Impunity - Report of the Independent Expert to Update the Set of Principles to Combat Impunity by Diane Orentlicher: Addendum - Updated Set of Principles for the Protection and Promotion of Human Rights through Action to Combat Impunity' (2005) E/CN.4/2005/102/Add.1.

${ }^{56}$ Arrest Warrant of 11 April 2000 (Democratic Republic of the Congo v. Belgium) (n 21) [31] [Dissenting Opinion of Judge Van den Wyngaert].

${ }^{57}$ See generally Arrest Warrant of 11 April 2000 (Democratic Republic of the Congo v. Belgium) (n 21) [Dissenting Opinion of Judge Al-Khasawneh].
} 


\section{CONCLUSION}

The maintenance of peaceful relations among States requires that Heads of State be granted appropriate immunities from jurisdiction before the courts of foreign States. For the sake of maintaining an environment in which Heads of State can carry out their international duties while visiting foreign countries, Head of State immunity should certainly afford protection from criminal responsibility. However, when Heads of State are suspected of having committed violations of fundamental human rights, they should not be exempt from punishment; in other words, immunity should not amount to impunity. At this point, it should be noted that while the doctrine of immunity should be maintained, this doctrine should no longer apply to situations in which transgression of fundamental human rights recognised as a peremptory norm of general international law has occurred. Impunity always 'presents a challenge to those responsible for preventing violations of fundamental human rights and establishing a just society. When impunity is allowed, it may become a significant obstacle to justice and peace'. ${ }^{58}$

Former United Nations Secretary General Kofi Annan reinforced the rationale behind Article 27 of the Rome Statute when he asserted that:

in the prospect of an international criminal court lies the promise of universal justice. That is the simple and soaring hope of this vision. We are close to its realisation. We will do our part to see it through till the end. We ask you to do yours in our struggle to ensure that no ruler, no State, no junta and no army anywhere can abuse human rights with impunity. Only then will the innocents of distant wars and conflicts know that they, too, may sleep under the cover of justice; that they, too, have rights, and that those who violate those rights will be punished. ${ }^{59}$

Head of State immunities are considered to be an essential element of international relations and international law. However, they are not jus cogens in nature. The protection of fundamental human rights should override these procedural immunities. Political concerns may not allow States to waive the immunity of their own high-ranking officials, but as Lauterpacht rightly noted, the 'dignity of a foreign state may suffer more from an appeal to immunity than from a denial of it'. ${ }^{60}$ Immunity from jurisdiction should on no account be applicable to fundamental human rights violations under international law which meet the threshold of a jus cogens norm, neither before domestic courts nor before international courts. Heads of State should not be allowed to enjoy immunities when violations of such human rights have been committed.

\footnotetext{
58 Ozdan (n 2) 51.

59 'Establishment of an International Criminal Court: Overview' (Rome Statute of the International Criminal Court, 1999) <http://legal.un.org/icc/general/overview.htm> accessed 05 July 2018.

${ }^{60} \mathrm{H}$ Lauterpacht, 'The Problem of Jurisdictional Immunities of Foreign States' (1951) 28 British Year Book of International Law 220, 232.
} 


\section{REFERENCES}

\section{Books and Journals}

Akande D, 'The Legal Nature of Security Council Referrals to the ICC and Its Impact on Al Bashir’s Immunities’ (2009) 7 Journal of International Criminal Justice 333

Akande D and Shah S, 'Immunities of State Officials, International Crimes, and Foreign Domestic Courts’ (2010) 21 European Journal of International Law 815

Brody R and Ratner M (eds), The Pinochet Papers: The Case of Augusto Pinochet Ugarte in Spain and Britain (Kluwer Law International 2000)

Cassese A, 'When May Senior State Officials Be Tried for International Crimes? Some Comments on the Congo v. Belgium Case' (2002) 13 European Journal of International Law 853

Criddle EJ and Fox-Decent E, ‘A Fiduciary Theory of Jus Cogens’ (2009) 34 Yale Journal of International Law 331

Cryer R and others, An Introduction to International Criminal Law and Procedure (2nd edn, Cambridge University Press 2010)

Fomerand J, Historical Dictionary of Human Rights (Rowman \& Littlefield 2014)

Fox QC H and Webb P, The Law of State Immunity (3rd edn, Oxford University Press 2013)

Gaeta P, 'Official Capacity and Immunities' in Antonio Cassese, Paola Gaeta and John RWD Jones (eds), The Rome Statute of the International Criminal Court: A Commentary, vol I (Oxford University Press 2002)

_ _ ' 'Does President Al Bashir Enjoy Immunity from Arrest?' (2009) 7 Journal of International Criminal Justice 315

Goldmann M, 'Arrest Warrant Case (Democratic Republic of the Congo v Belgium)', Max Planck Encyclopedia of Public International Law (MPEPIL) (Oxford University Press 2009)

Lauterpacht H, ‘The Problem of Jurisdictional Immunities of Foreign States’ (1951) 28 British Year Book of International Law 220

Minnerop P and others, World Court Digest 2001 - 2005, vol 4 (Springer Science \& Business Media 2009)

Moghalu KC, 'Reconciling Fractured Societies: An African Perspective on the Role of Judicial Prosecutions' in Ramesh Chandra Thakur and Petrus Adrianus Maria Malcontent (eds), From Sovereign Impunity to International Accountability: The Search for Justice in a World of States (United Nations University Press 2004) 
Morris M, 'The Democratic Dilemma of the International Criminal Court' (2002) 5 Buffalo Criminal Law Review 591

Needham J, 'Protection or Prosecution for Omar Al Bashir? The Changing State of Immunity in International Criminal Law’ (2011) 17 Auckland University Law Review 219

Orakhelashvili A, 'Arrest Warrant of 11 April 2000 (Democratic Republic of the Congo v. Belgium)’ (2002) 96 American Journal of International Law 677

Ozdan S, 'Immunity vs. Impunity in International Law: A Human Rights Approach' (2018) 4 Baku State University Law Review 36

Papillon S, 'Has the United Nations Security Council Implicitly Removed Al Bashir's Immunity?' (2010) 10 International Criminal Law Review 275

Pierson C, 'Pinochet and the End of Immunity: England's House of Lords Holds That a Former Head of State Is Not Immune for Torture' (2000) 14 Temple International and Comparative Law Journal 263

Solis GD, The Law of Armed Conflict: International Humanitarian Law in War (Cambridge University Press 2010)

Stern B, 'Immunities for Heads of State: Where Do We Stand?’ in Mark Lattimer and Philippe Sands (eds), Justice for Crimes Against Humanity (Hart Publishing 2003)

Tunks M, 'Diplomats or Defendants? Defining the Future of Head-of-State Immunity' (2002) 52 Duke Law Journal 651

Watts SA, The Legal Position in International Law of Heads of States, Heads of Governments and Foreign Ministers, vol 247 (Martinus Nijhoff Publishers 1994)

Wuerth I, 'Pinochet’s Legacy Reassessed’ (2012) 106 The American Journal of International Law 731

\section{Cases}

Arrest Warrant of 11 April 2000 (Democratic Republic of the Congo v Belgium) (2002) I.C.J. Reports

In re Grand Jury Proceedings [1987] United States Court of Appeals, Fourth Circuit 700, 1108817 F2d

Prosecutor v Tihomir Blaskic (1997) 110 ILR 687 (International Criminal Tribunal for the Former Yugoslavia) 
$R v$ Bow Street Metropolitan Stipendiary Magistrate and Others, ex parte Pinochet Ugarte (No 1) (1998) 4 AII ER (House of Lords)

$R v$ Bow Street Metropolitan Stipendiary Magistrate and Others, ex parte Pinochet Ugarte (No 2) (1999) 2 W.L.R. 272 (House of Lords)

$R v$ Bow Street Metropolitan Stipendiary Magistrate and Others, ex parte Pinochet Ugarte (No 3) (2000) 1 A.C. 147 (House of Lords)

The Prosecutor v Al Bashir, First Arrest Warrant (2009) ICC-02/05-01/09 (Pre-Trial Chamber I)

The Prosecutor v Al Bashir, Second Arrest Warrant (2010) ICC-02/05-01/09-95 (PreTrial Chamber I)

The Prosecutor v Omar Al Bashir (2013) ICC-02/05-01/09-151 (Pre-Trial Chamber II)

The Prosecutor v Omar Al Bashir (2015) ICC-02/05-01/09-242 (Pre-Trial Chamber II)

Yousuf v Samantar (2012) 699 F 3d 763 (Court of Appeals, 4th Circuit)

\section{United Nations and Other Official Documents}

Belgium: Act of 1999 Concerning the Punishment of Grave Breaches of International Humanitarian Law 1999

Convention on the Prevention and Punishment of the Crime of Genocide Adopted by General Assembly of the United Nations (United Nations Treaty Series 1948) 78

International Military Tribunal for the Far East Charter (1946)

Kolodkin RA, 'Second Report on Immunity of State Officials from Foreign Criminal Jurisdiction, 62nd Session’ (International Law Commission 2010) UN Doc. A/CN.4/631

Nuremberg Trial Proceedings Vol. 1 - Charter of the International Military Tribunal

Peace Treaty of Versailles 1919

Principles of International Law Recognized in the Charter of the Nuremberg Tribunal and in the Judgment of the Tribunal, 5 UN GAOR Supp. (No. 12) at 11, U.N. Doc. A/1316

Rome Statute of the International Criminal Court (UN General Assembly 2002)

United Nations Commission on Human Rights, 'The Administration of Justice and the Human Rights of Detainees, Question of the Impunity of Perpetrators of Human Rights Violations (Civil and Political) Revised Final Report Prepared by Mr. Joinet Pursuant to Sub-Commission Decision 1996/119' (1997) UN Doc. E/CN.4/Sub.2/1997/20/Rev.1

— Expert to Update the Set of Principles to Combat Impunity by Diane Orentlicher: 
Addendum - Updated Set of Principles for the Protection and Promotion of Human Rights through Action to Combat Impunity' (2005) E/CN.4/2005/102/Add.1

UN Security Council, Statute of the International Criminal Tribunal for the Former Yugoslavia, SC res. 827, UN SCOR 48th sess., 3217th mtg. at 1-2 1993

\section{Online Sources}

Bashir-Watch <http://bashirwatch.org/> accessed 05 July 2018

Establishment of an International Criminal Court: Overview (Rome Statute of the International Criminal Court, 1999)

<http://legal.un.org/icc/general/overview.htm> accessed 05 July 2018 